\title{
THEORETICAL INVESTIGATION OF CONCRETE FILLED STEEL HOLLOW SECTION COLUMNS
}

\author{
A. S. Abdel-zaher ${ }^{1}$, L. M. Abdel-Hafez ${ }^{2}$, Y. R. Tawfic ${ }^{3}$ and M. E. Abdel-fattah ${ }^{4}$ \\ ${ }^{1}$ Ass. Lecture of civil engineering department, the Higher Institute for Engineering \\ and Technology- El-Mina \\ Email: A.saudi@mhiet.edu.eg \\ ${ }^{2}$ Prof. and Head of civil Engineering Department, Faculty of Engineering, Nahda University, \\ Email: Laila.shaddy@nub.edu.eg \\ ${ }^{3}$ Associate prof. of civil engineering department, Faculty of Engineering, Minia University, \\ Email: yasser_rifat@yahoo.com \\ ${ }^{4}$ Lecture of civil engineering department, Faculty of Engineering, Minia University, \\ Email: dr.eng.m.eid@hotmail.com
}

\begin{abstract}
Steel concrete composite columns are widely used in high rise buildings and bridges. Composite columns provide not only great reduction for the column size and weight, but also high columns efficiency and ductility. In Concrete Filled Steel Tube (CFST) columns, the steel tube provides formwork for the concrete; the concrete prevents local buckling of the steel tube. This paper illustrates a theoretical study of the behavior of CFST columns subjected to centric load by using ANSYS (18.1). The study divided into two parts. In the first part, the verification of the program was done using an experimental work of previous research, this verification showed that the capability of ANSYS program for analysis of the CFST columns with very good accuracy. In the second part: a parametric study was carried out to study the behavior of CFST braced, constant cross section area, centric loaded columns. The main variables were the shape of cross section (three shapes: square, rectangular and circular) and slenderness ratio $(\lambda)$. The analysis shows that the increase of the slenderness ratio led to decrease the ultimate load capacity, stiffness and ductility of the CFST columns. The current ECP of concrete code underestimates the values of ultimate load capacity while, ECP of steel predicts the reasonable values for an ultimate load capacity of CFST columns.
\end{abstract}

Keywords: Concrete Filled Steel Tube, slenderness ratio.

\section{INTRODUCTION:}

The Concrete Filled Steel Hollow Section (CFSHS) columns are increasingly used in high rise building, bridges and other types of structures. The steel concrete composites are considered as an advantage system for carrying large axial load benefitting from the interaction between the concrete and the steel section. The concrete in a composite column reduces the potential for buckling of steel section in addition to resisting compressive loading.
Jingfeng Wang, Beibei Li, Jinchao Li [7], an experimental and numerical research on the seismic performance of semi-rigid concrete-filled steel tubular (CFST) frames with external sandwich composite wall panels (SCWPs) was reported. Four specimens of semi-rigid CFST frames with external SCWPs and one specimen of pure semi-rigid CFST frame subjected to lowcyclic loading were conducted. Failure modes, horizontal load versus displacement relation curves were analyzed. The test specimens exhibited good hysteretic - 63 - 
behavior، energy dissipation and ductility. Finite element (FE( analysis modeling was developed and the results obtained from the FE model matched well with the experimental results. Extensive parametric studies have been carried out to investigate the effect of steel strength, column slenderness ratio and steel wire diameter of wall, etc. on the strength and stiffness of the typed composite frames. The opening ratio and location of the SCWPs were also discussed. The experimental study and numerical analysis will provide the scientific basis for design theory and application of the SCWPs in fabricated steel structure building.

Oliveira et al. [9], Also tested 32 CFST columns in axial compression. All these specimens had a steel section of outer diameter $114.3 \mathrm{~mm}$ and tube thickness 3.35 $\mathrm{mm}$. Four different L/D values, viz. 3, 5, 7 \& 10 were used in conjunction with 4 different compressive strength of concrete having 30,60, 80 and $100 \mathrm{MPa}$. It was observed that short columns $(\mathrm{L} / \mathrm{D}=3)$ filled with normal strength concrete generally collapsed a strain hardening behavior due to the confinement offered by steel section. The inherent brittleness of high strength concrete tends to cancel out due to the confinement offered by steel section; therefore a gradual strain softening was observed for steel tubes filled with $80 \mathrm{MPa}$ and $100 \mathrm{MPa}$ compressive strength of concrete.

Han et al. [4] Studied a series of tests on the Concrete Filled Double skin Steel Tubular (CFDST) columns subjected to static loading, including 37 columns under axial compression, 13 columns under bending and 42 columns under eccentric compression, respectively $[5,10,11]$. It was found that the behavior of CFDST columns is generally similar to that of the traditional CFDST columns. This is owing to the fact that, the section slenderness support to the sandwiched concrete. Otherwise, the premature local buckling of inner steel tubes will have adverse effects on the loadcarrying and deformation capacities of CFDST columns. As can be seen, the failure modes of the inner concrete and the outer tube of CFDSTs are generally similar to those of conventional CFDSTs.

The objective of this research was investigating the effect of the slenderness ratio of CFST braced columns with constant cross section area, centric loaded columns.

\section{FINITE ELEMENT IDEALIZATION:}

\section{2-1 Elements used in the analysis:}

Concrete (Solid65): is used for the threedimensional modeling of solids with or without reinforcing bars (re-bars). It is capable of cracking in tension and crushing in compression. Eight nodes having three degrees of freedom at each node define the element: translations in the nodal $\mathrm{x}, \mathrm{y}$, and $\mathrm{z}$ directions. The element is capable of plastic deformation, cracking in three orthogonal directions, and crushing. The geometry and node locations are shown in figure (1-a).

Steel section (SOLID185): is used for 3-D modeling of solid structures as shown in figure (1-b). It is defined by eight nodes having three degrees of freedom at each node: translations in the nodal ( $\mathrm{x}, \mathrm{y}$, and $\mathrm{z}$ ) directions. The element has plasticity, hyper elasticity, stress stiffening, creep, large deflection, and large strain capabilities. 


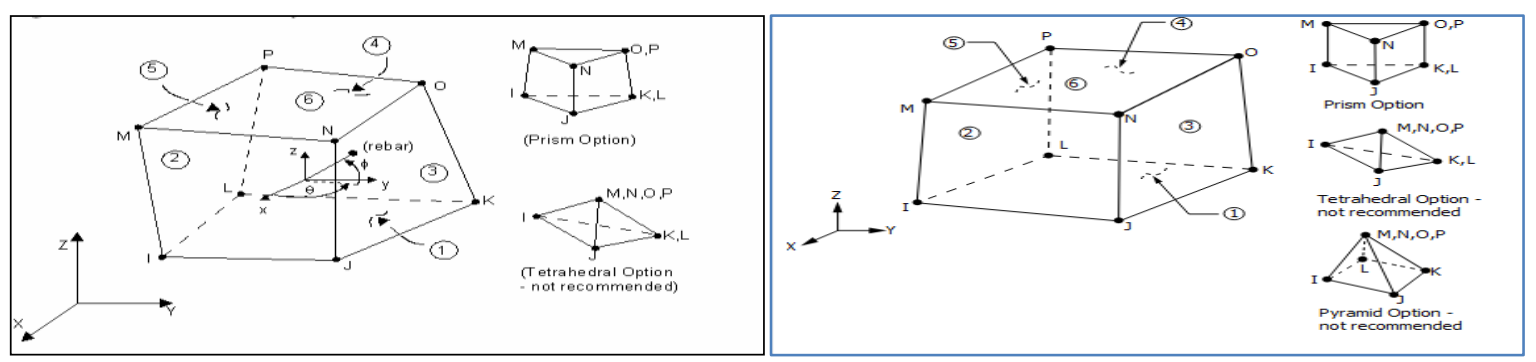

(a)

(b)

Fig.1. Geometrical elements: (a) SOLID 65, (b) SOLID 185

\section{2-2 The yield criterion:}

Quasi- Material parameters are hardening rules, which describe the change of position of the subsequent yielding surface during plastic deformation, concrete tension cracking modeling aggregate interlocking effects and tension stifling effects. A two-parameter Drucker-Prager yield criterion $[1,8]$ Was used to model the behavior of concrete under threedimensional states of stress

\section{0}

$$
f c\left(I_{1}, J_{2}\right)=\alpha I_{1}+\sqrt{J_{2}}-K=
$$

In the previous equation, $\boldsymbol{I}_{\mathbf{1}}$ and $\boldsymbol{J}_{\mathbf{2}}$ are the first invariant of the stress tensor and the second invariant of the stress deviator tensor, respectively; $\alpha$ and $\mathrm{k}$ are the positive model parameters that are functions of cohesion and the friction angle. Also, a smeared concrete cracking model and a strain-based concrete crushing model, are used along with Drucker-Prager yield criterion. A friction angle of 35 degrees with a cohesion value of $\mathrm{fc}^{\prime} / 4$ was used [1,6] and $\mathrm{k}$ are the positive model parameters that are functions of cohesion and the friction angle. A friction angle of $\left(35^{\circ}\right)$ degrees with a cohesion value of $f_{\mathrm{c}} / 4$ was used [1,7]. Note that in this study an associative flow rule is utilized. In ANSYS, the Drucker-Prager yield criterion supports an elastic-perfectly plastic stress-strain relationship. A modulus of elasticity of $\left(0.7 f_{c} / \varepsilon 0\right)$ is used [1,9], which is a reasonable linearization of the ascending branch of the concrete stressstrain relationship up to the peak stress. ( $\mathbf{\varepsilon} 0$ is the concrete strain at the ultimate compressive strength $\boldsymbol{f}_{\mathrm{c}}$ ). The concrete crushing capability available in ANSYS is stress-based; however, a strain-based crushing model is more appropriate in modeling confined as well as unconfined concrete. The available smeared concrete cracking model in ANSYS is used.

\section{VERIFICATION PROGRAM:}

Four square stub columns and six circular stub columns tested experimentally under concentric axial compression load by reference [6] were analyzed using ANSYS (18.1). All tested columns have the same height $(300 \mathrm{~mm})$ and the width or diameter column $(150 \mathrm{~mm})$. The main variables were tube thickness $(3,4,5) \mathrm{mm}$ and grade of concrete $(25,60) \mathrm{MPa}$. The details of the analyzed columns are shown in Figure (3) and table (1). The properties of material are taken in the modeling, modulus of elasticity $\mathrm{E}_{\mathrm{c}}=4700 \sqrt{f^{\prime} c}, \mathrm{Es}=200 \mathrm{GPa}$, Poison ratio ( $v=0.2$ for concrete, $v=0.3$ for tube thickness).

\section{3-1 Mesh idealization, Loading and boundary conditions:}

A very fine mesh was used to have accurate results as shown in [Figure-3]. The model should be constrained by using displacement condition to get achieved solution. From figure (2) it can be seen that: the boundary conditions were applied to simulate the experimental module end conditions. The applied load is acted by dividing the total load on the top nodes of 
the column. The concrete columns were modeled using by SOLID 65. Also, tube thickness and steel plate under the column were modeled using by SOLID185, it can see that in Figure (2). The interface between solid185 which modeled the tube thickness

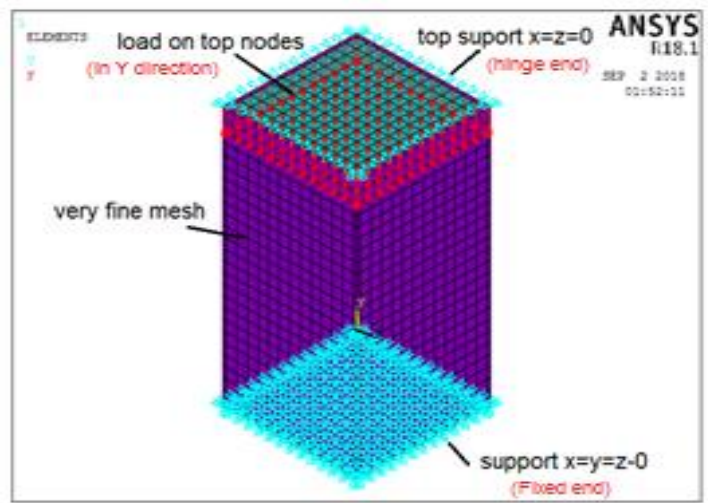

Fig.2. Meshing, location of load and solid 65 which modeled the column concrete is defined by the standard (allow sliding surface vertical and separation) and the friction coefficient is $(0.30)$. The contact cohesion is $(0.01)$ face.

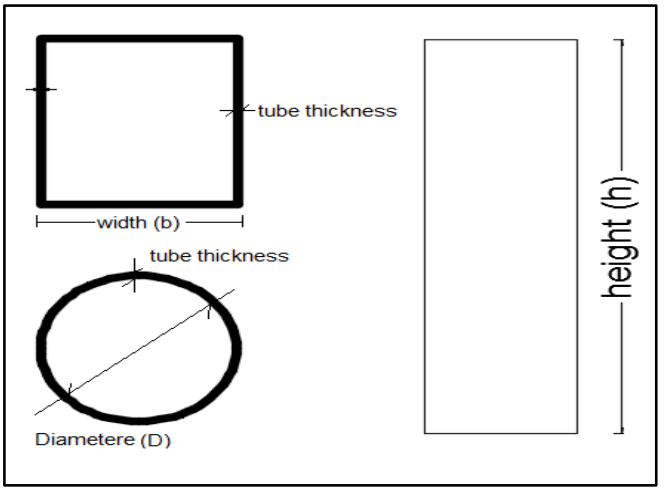

Fig.3. Geometry of tested columns and support of model column

Table1. Details of analyzed columns [6]

\begin{tabular}{|c|c|c|c|c|}
\hline $\begin{array}{c}\text { Shape of } \\
\text { column }\end{array}$ & No. of columns & $\begin{array}{c}\text { Thickness } \\
(\mathrm{mm})\end{array}$ & $\mathbf{F}_{\mathbf{c}}{ }^{\prime} \mathrm{MPa}$ & $\mathbf{F}_{\mathbf{y}} \mathrm{MPa}$ \\
\hline \multirow{4}{*}{ Square } & SF-N-2-A & 4 & 25 & 306 \\
\cline { 2 - 5 } & SF-H-2-B & 4 & 60 & 306 \\
\cline { 2 - 5 } & SF-N-3-A & 5 & 25 & 285 \\
\cline { 2 - 5 } & SF-H-3-B & 5 & 60 & 285 \\
\hline \multirow{4}{*}{ Circular } & CH-1 & 3 & ---- & 252 \\
\cline { 2 - 5 } & CF-N-1-A & 3 & 25 & 252 \\
\cline { 2 - 5 } & CF-H-1-B & 3 & 60 & 252 \\
\cline { 2 - 5 } & CH-2 & 4 & ---- & 306 \\
\cline { 2 - 5 } & CF-N-2-A & 4 & 25 & 306 \\
\cline { 2 - 5 } & CF-H-2-B & 4 & 60 & 306 \\
\hline
\end{tabular}

F'c: average compressive strength of column, Fy: yield strength of steel tube, $\mathbf{N}=$ Normal concrete, $\mathbf{H}=$ High strength concrete

\section{3-1 Analysis and comparison of the results of experimental work:}

Table (2) summarizes the experimental results, theoretical results and the comparisons between experimental and theoretical results for ultimate load and ultimate horizontal displacement. Figures from (4) to (13) show the comparisons between the experimental load-displacement curves and the corresponding theoretical values.

\section{3-1-1 Load-displacement curves:}

In figures from (4) to (13), the loaddisplacement curves for all models which tested experimentally and analyzed using ANSYS program are shown. The correlation is very good between the experimental and analytical curves. The analysis predicts stiffer displacement values at initiation curve, may be due to the effect of modulus of elasticity of concrete. Because of the modulus of elasticity was calculated by the empirical equation not calculated experimentally. 
Table2. Comparison of experimental and theoretical tested results of columns

\begin{tabular}{|c|c|c|c|c|c|c|c|}
\hline \multirow{2}{*}{$\begin{array}{c}\text { Shape } \\
\text { of } \\
\text { column }\end{array}$} & \multirow{2}{*}{$\begin{array}{l}\text { No. of } \\
\text { columns }\end{array}$} & $\mathbf{P}_{\text {ult. (exp.) }}$ & $\begin{array}{c}\mathbf{P}_{\text {ult. }} \\
\text { (theo.) }\end{array}$ & \multirow{2}{*}{$\frac{\underline{\mathbf{P}}_{\text {ult._(theo.) }}}{\mathbf{P}_{\text {ult. (exp.) }}}$} & \multirow{2}{*}{$\begin{array}{c}\boldsymbol{\delta}_{\mathbf{u}} \\
(\text { exp. })\end{array}$} & \multirow{2}{*}{$\begin{array}{c}\boldsymbol{\delta}_{\mathbf{u}} \\
\text { (theo.) }\end{array}$} & \multirow{2}{*}{$\begin{array}{l}\underline{\boldsymbol{\delta}}_{\mathbf{u}}(\text { theo.) } \\
\boldsymbol{\delta}_{\mathbf{u}(\text { exp. })}\end{array}$} \\
\hline & & $\mathrm{KN}$ & $\mathrm{KN}$ & & & & \\
\hline \multirow{4}{*}{ 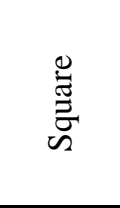 } & SF-N-2-A & 1215 & 1230 & 1.01 & 3 & 3.12 & 1.04 \\
\hline & SF-H-2-B & 1543 & 1590 & 1.03 & 2.91 & 3.17 & 1.09 \\
\hline & SF-N-3-A & 1300 & 1330 & 1.02 & 2.61 & 2.77 & 1.06 \\
\hline & SF-H-3-B & 1615 & 1534.3 & 0.95 & 3.1 & 3.3 & 1.06 \\
\hline \multirow{6}{*}{ 䒿 } & CH-1 & 423 & 410 & 0.97 & 1.4 & 1.57 & 1.12 \\
\hline & CF-N-1-A & 964 & 956.94 & 0.99 & 2.68 & 2.89 & 1.08 \\
\hline & CF-H-1-B & 1177 & 1127.4 & 0.96 & 2.15 & 2.36 & 1.10 \\
\hline & $\mathrm{CH}-2$ & 457 & 571.7 & 1.25 & 1.1 & 1.21 & 1.10 \\
\hline & CF-N-2-A & 1071 & 1080 & 1.01 & 2.3 & 2.62 & 1.14 \\
\hline & CF-H-2-B & 1320 & 1346.8 & 1.02 & 2 & 2.22 & 1.11 \\
\hline
\end{tabular}

$\mathbf{P}_{\text {ult (exp.): }}$ experimental ultimate load, $\mathbf{P}_{\text {ult (theo.): }}$ theoretical ultimate load, $\boldsymbol{\delta}_{\mathbf{u}(\text { (exp.): }}$ : experimental max. displacement, $\boldsymbol{\delta}_{\mathbf{u}(\text { theo.) }}$ : theoretical max. displacement.

\section{3-1-2 Ultimate load:}

Table (2) summarizes the comparison between the experimental and

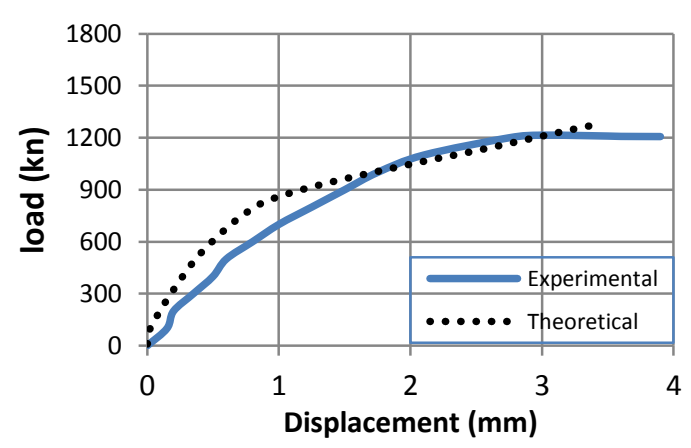

Fig.4. Comparison of experimental and theoretical of load-displacement curve for col. SF-N-2-A

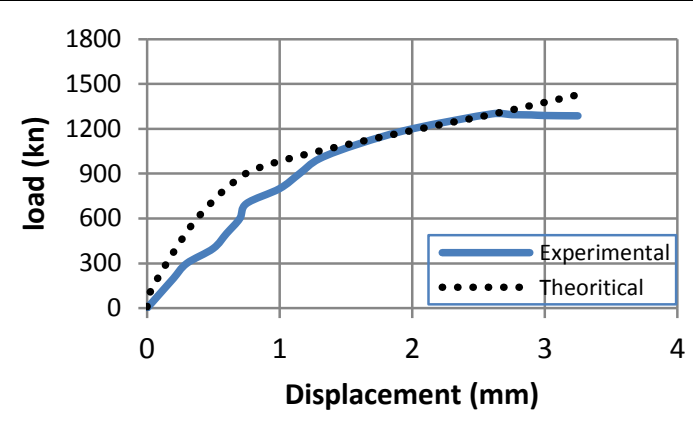

Fig.6. Comparison of experimental and theoretical of load-displacement curve for col. SF-N-3-A the theoretical results for all models. From this table, it can be seen that: the theoretical results are compared well with those experimental results.

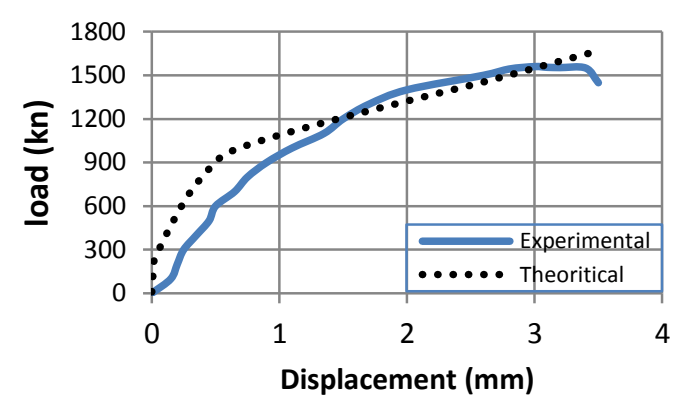

Fig.5. Comparison of experimental and theoretical of load-displacement curve for col. SF-H-2-B

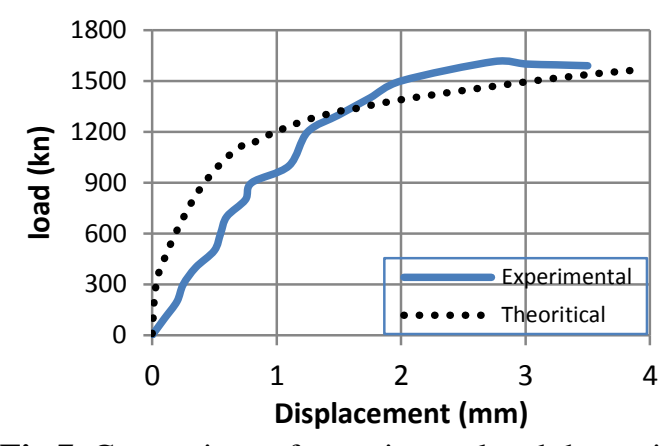

Fig.7. Comparison of experimental and theoretical of load-displacement curve for col.SF-H-3-B 


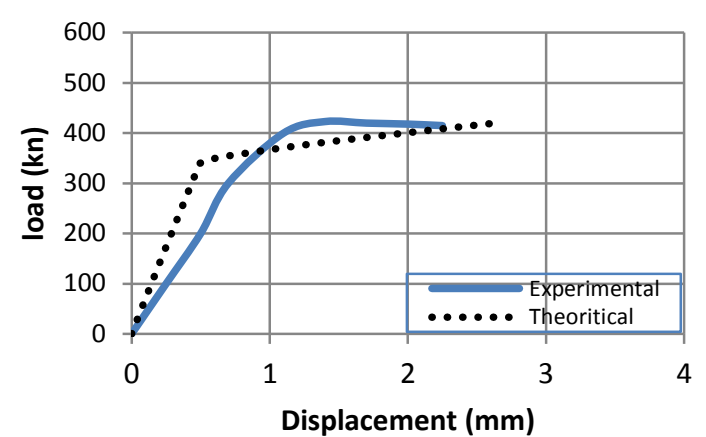

Fig. 8. Comparison of experimental and theoretical of load-displacement curve for col. $\mathrm{CH}-1$

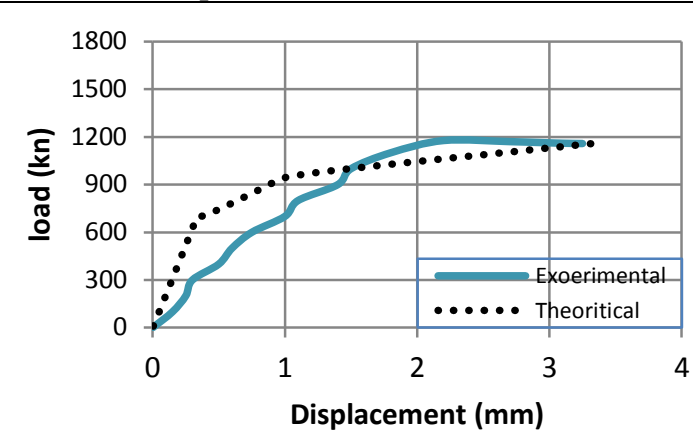

Fig. 10. Comparison of experimental and theoretical of load-displacement curve for col. CF-H-1-B

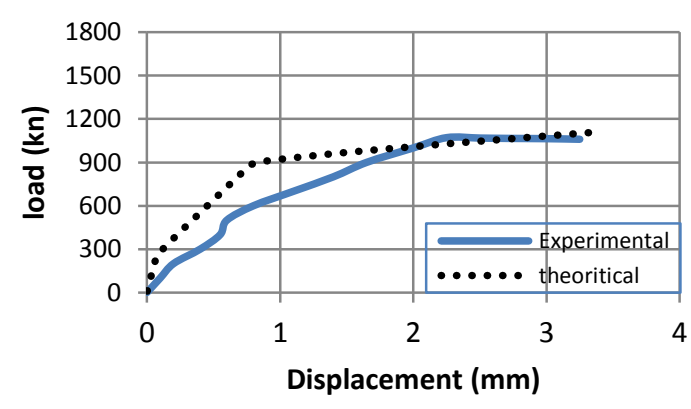

Fig. 12. Comparison of experimental and theoretical of load-displacement curve for col. CF-N-2-A

\section{THE CASE STUDY:}

Nine partially fixed at base, hinged at top and centric loaded CFST braced columns were analyzed using ANSYS program. These columns were identical in cross sectional area (concrete and steel) but differ in the shape of the cross section and column height.

\section{4-1 Details of the analyzed specimens:}

The nine CFST columns were divided into 3 groups depending on the shape of the cross section (square,

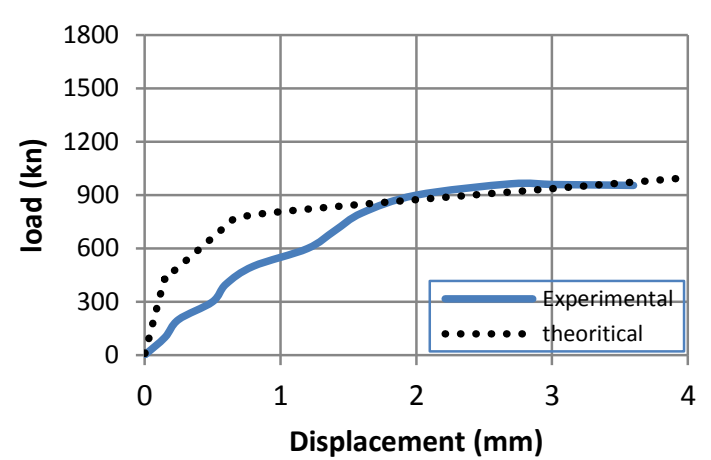

Fig. 9. Comparison of experimental and theoretical of load-displacement curve for col. CF-N-1-A

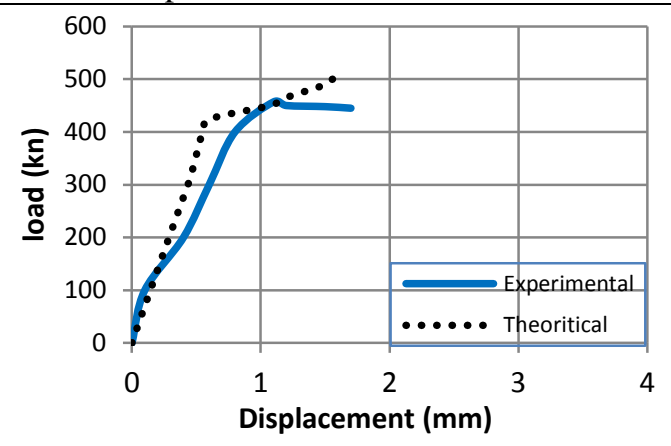

Fig. 11. Comparison of experimental and theoretical of load-displacement curve for col. $\mathrm{CH}-2$

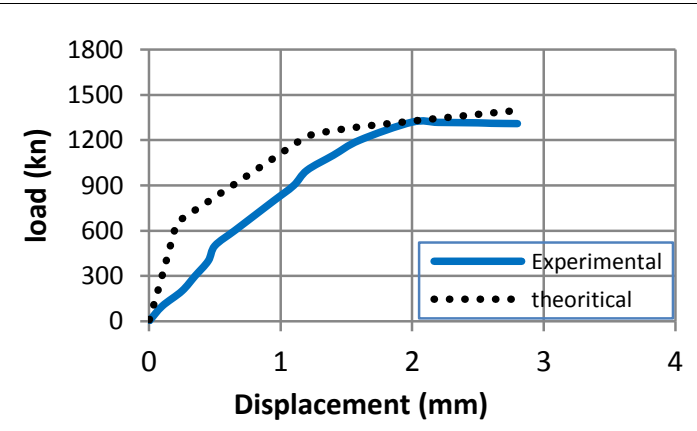

Fig. 13. Comparison of experimental and theoretical of load-displacement curve for col. CF-H-2-B

rectangular and circular). Each group includes three differ in height columns (1500mm, 2500mm, 3500mm). All CFST columns have $22500 \mathrm{~mm}^{2}$ concrete area, $1836 \mathrm{~mm}^{2}$ steel plate area, $300 \mathrm{MPa}$ yield strength of steel plate and $25 \mathrm{MPa}$ compressive strength of concrete. The main variable was the slenderness ratio (ג). Table (3) summarizes the details of the analyzed CFST columns. The boundary condition and loading system of the analyzed columns were given in Fig (14). 
Vol. 39, No. 1. January 2020

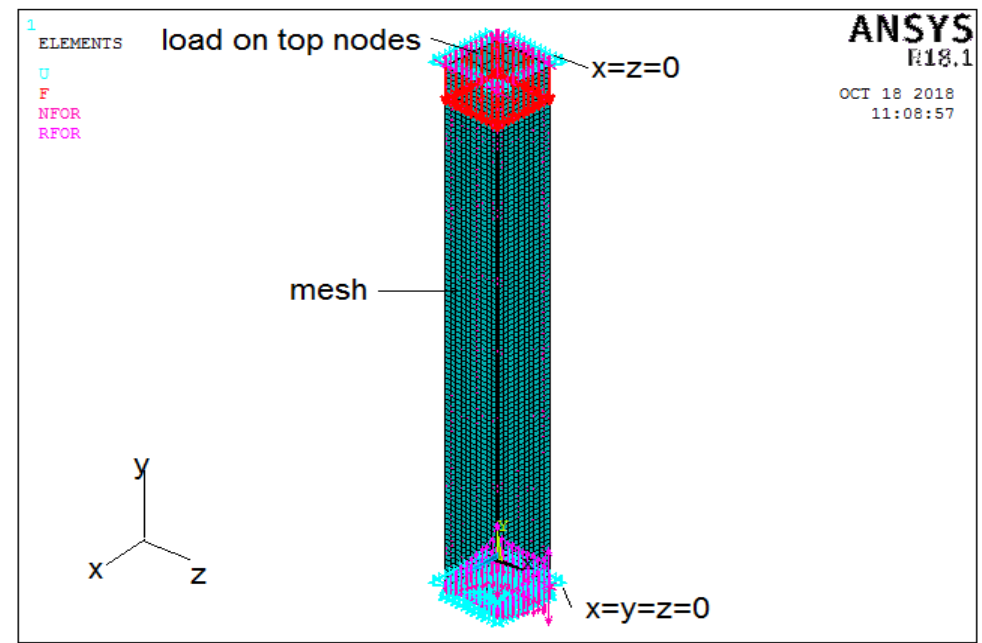

Fig.14. Meshing, location of loading and support of model CFST column

Table3. Details of CFST columns

\begin{tabular}{|c|c|c|c|c|c|}
\hline Specimens & $\begin{array}{c}\text { Dimension } \\
(\mathbf{m m})\end{array}$ & $\begin{array}{c}\text { Thickness } \\
(\mathbf{m m})\end{array}$ & $\begin{array}{c}\text { Length } \\
(\mathrm{mm})\end{array}$ & \multicolumn{2}{|c|}{$\begin{array}{l}\text { slenderness } \\
\text { ratio }(\AA)\end{array}$} \\
\hline $\mathrm{Sq}-1$ & \multirow{3}{*}{$150 \times 150$} & \multirow{3}{*}{3} & 1500 & \multicolumn{2}{|c|}{9.50} \\
\hline $\mathrm{Sq}-2$ & & & 2500 & \multicolumn{2}{|c|}{15.83} \\
\hline $\mathrm{Sq}-3$ & & & 3500 & \multicolumn{2}{|c|}{22.17} \\
\hline Rec-1 & \multirow{3}{*}{$100 \times 225$} & \multirow{3}{*}{2.78} & 1500 & 14.25 & 6.33 \\
\hline Rec-2 & & & 2500 & 23.75 & 10.56 \\
\hline Rec-3 & & & 3500 & 33.25 & 14.77 \\
\hline Cir-1 & \multirow{3}{*}{169.26} & \multirow{3}{*}{3.38} & 1500 & \multicolumn{2}{|c|}{8.42} \\
\hline Cir-2 & & & 2500 & \multicolumn{2}{|c|}{14.03} \\
\hline Cir-3 & & & 3500 & \multicolumn{2}{|c|}{19.64} \\
\hline
\end{tabular}

\section{4-2 Failure modes:}

Fig (15) shows the general mode of failure of the analyzed CFST columns. From this figure, it can be seen that; the overall member buckling very clear in long CFST column. All the $1500 \mathrm{~mm}, 2500 \mathrm{~mm}$, 3500mm columns failed largely by overall buckling. Overall instability was confirmed by the large slenderness ratio. This is evidence that overall flexural buckling was coupled with local instability, because of the large plate slenderness. 


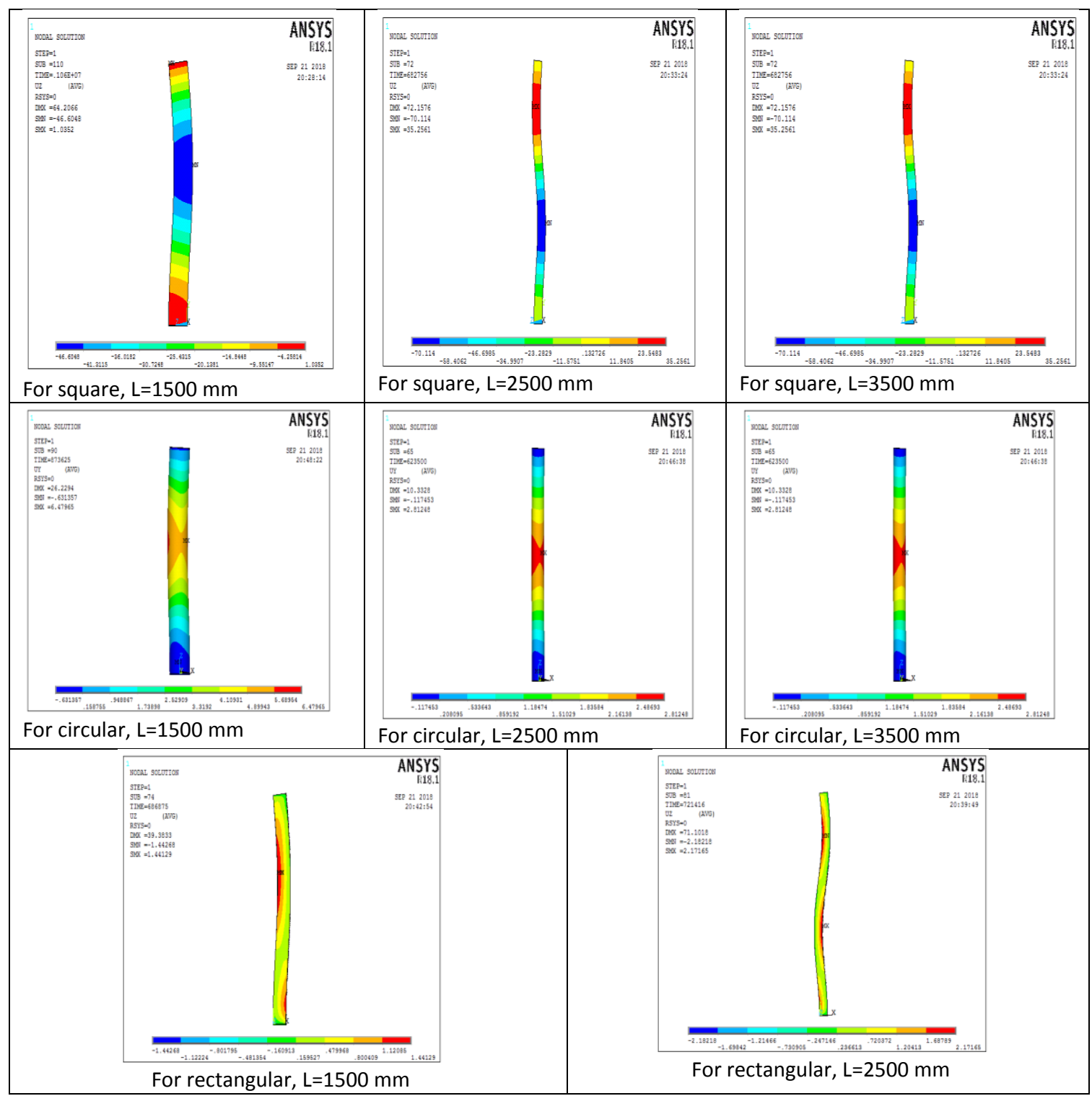

Fig.15 Failure modes for different shape of CFST columns

\section{4-3 Load-displacement curves:}

Figures 15 to 18 show the load horizontal displacement curves for the CFST columns. From these figures; it can be seen that the shorter CFST columns have a higher stiffness and load carrying capacity than the longer columns. Generally, the stiffness increases with decrease the slenderness ratio for constant area of the concrete and steel section. As the length of the CFST columns increases, the load carrying capacity decreases.

\section{4-3-1 the effect of slenderness ratio:}

For the square column: it can be observed from curves in figure (15) that; at the initial stage of loading: no effect of the slenderness ratio of the value of the the stiffness of CFST columns. At the plastic stage of loading (initial buckling): for column length $2.5 \mathrm{~m}$, have major loss of stiffness, but column length $1.5 \mathrm{~m}$ have slightly effect of the stiffness. At failure stage: there is major effect of the slenderness ratio $(\lambda)$ of CFST columns on the behavior especially for $\lambda=24.56$ (complete loss of the stiffness). At the last stages of loading, the horizontal displacement increases with decrease slenderness ratio. 
For the rectangular columns: which showing in figure (17) there is no effect of the slenderness ratio along the curves for all stages. Pre-buckling stiffness is the same after initial buckling; the major direction stiffer than the minor direction. The slenderness ratio for columns length $3.5 \mathrm{~m}$ out of range of the Egyptian code the program stopped at load near to Euler equation $\left(\lambda_{\text {max. code }}=30\right)$.
For the circular columns: it can be seen in figure (18) that there; at the initial stage of loading there is no effect of of the slenderness ratio of the value of the horizontal displacement and stiffness but, for (long column) $\lambda=21.77$ have major loss of stiffness and high value of the horizontal displacement for the same load compared to (short column) $\lambda=15.55,9.32$ due to the edges of square and rectangular cross section works as stiffner to each other. At the plastic stage: there is major loss of the stiffness for all the slenderness ratio $(\lambda)$ of CFST columns.

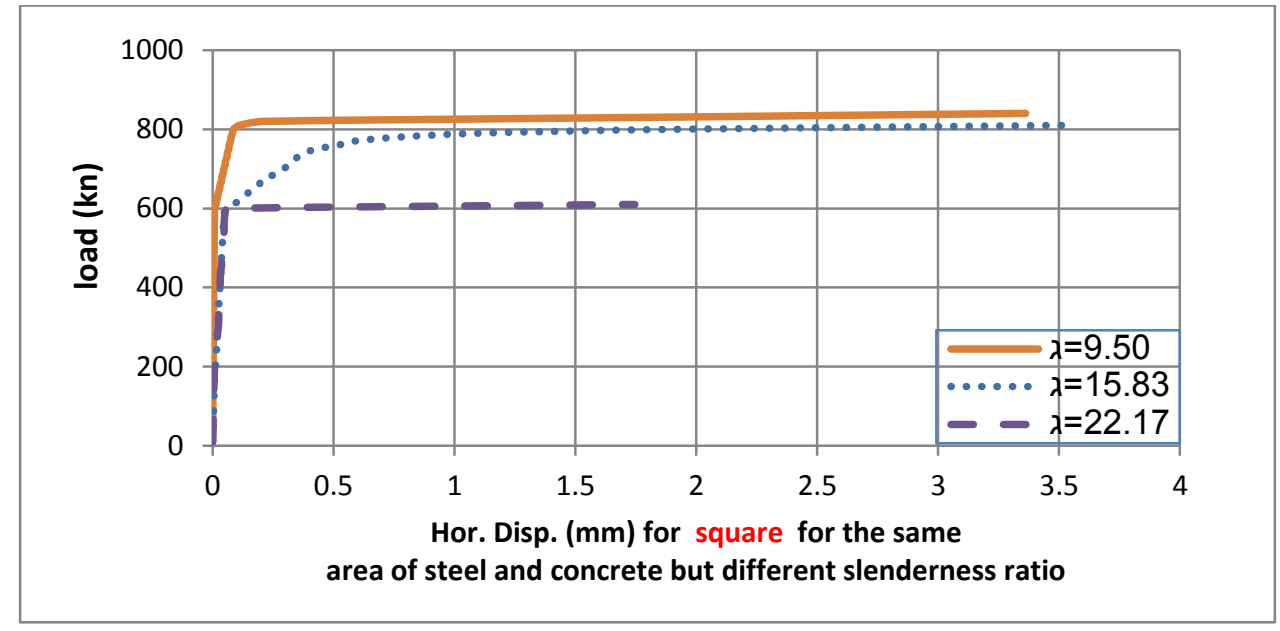

Fig.15. The load-displacement curve for square column

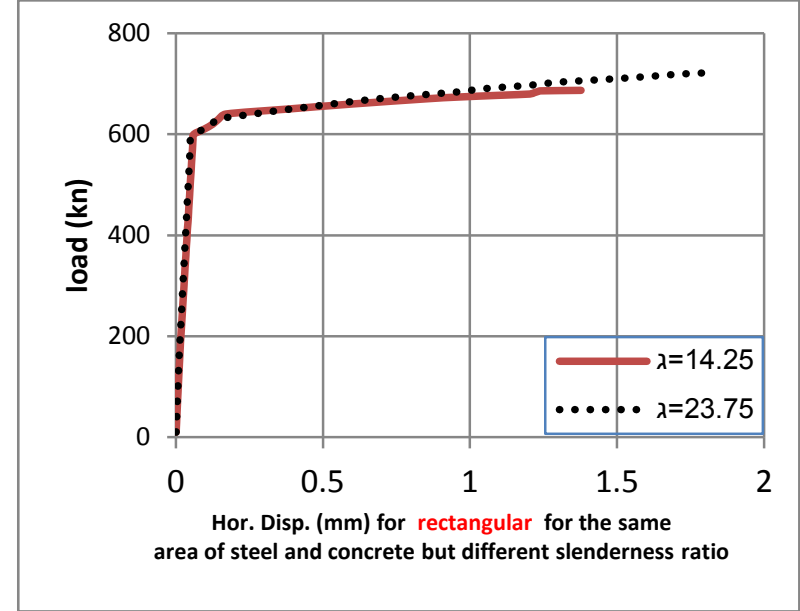

a) minor direction

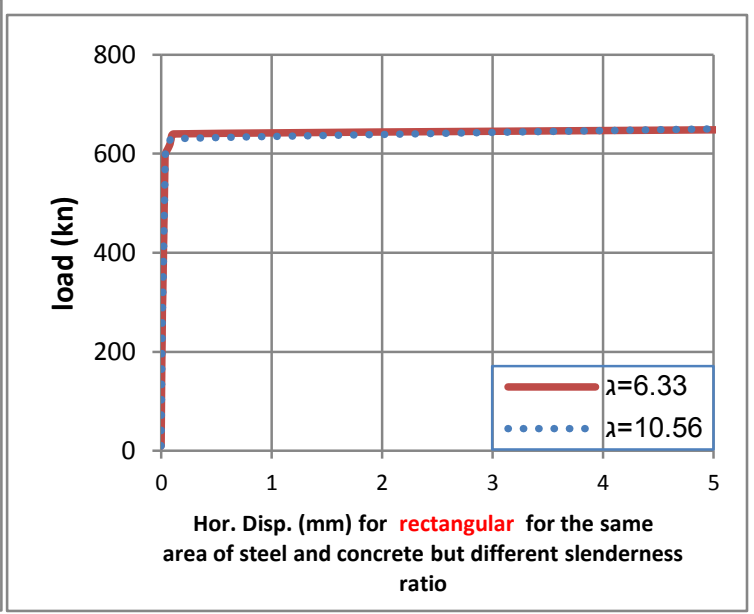

b) Major direction

Fig.16. The load-displacement curve for rectangular column 
Vol. 39, No. 1. January 2020

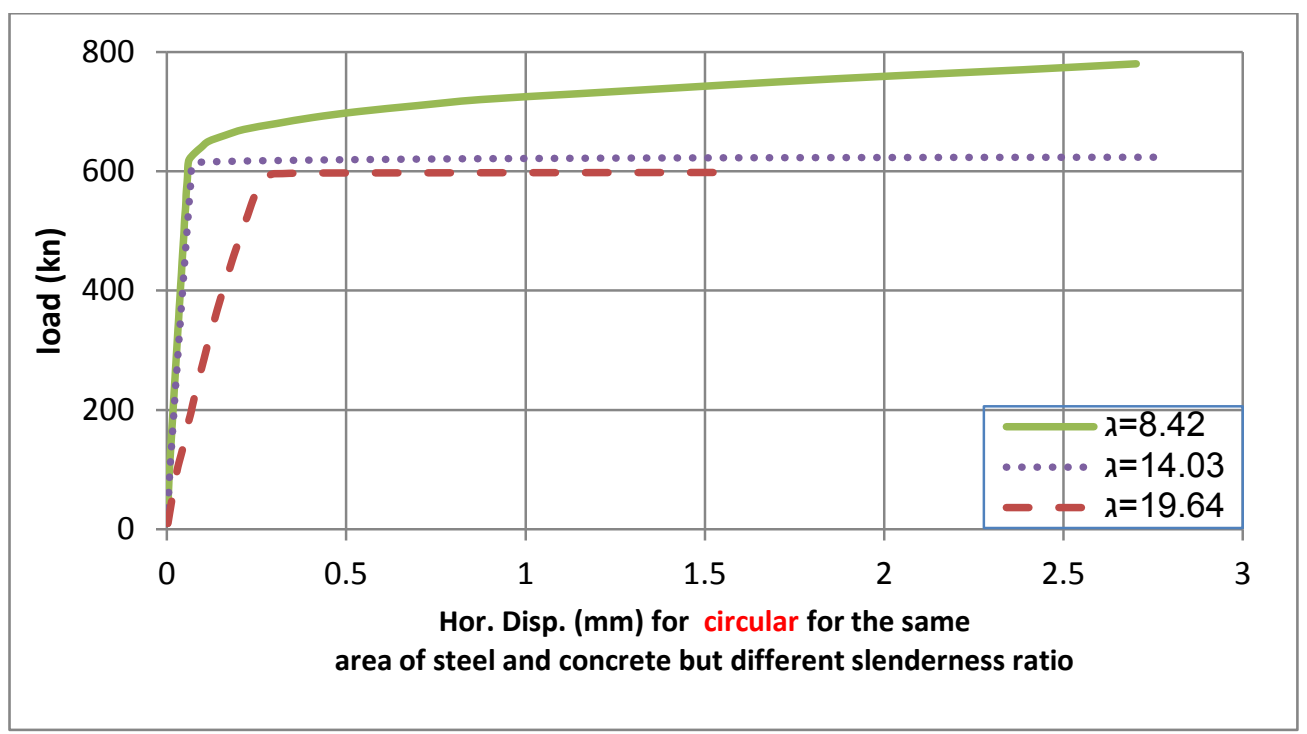

Fig.17. The load-displacement curve for circular column

\section{4-3-2 the effect of the shape of columns:}

Figure 18 shows the load -horizontal displacement curves for the CFST columns which have different columns shapes. From these figures it can be observed that; at the elastic stage: no effect on the value of the horizontal displacement and the stiffness of CFST columns shapes. At the plastic stage: the rectangular column section and the circular section have major loss of the stiffness compared to the square column section, due to have a higher moment of inertia.

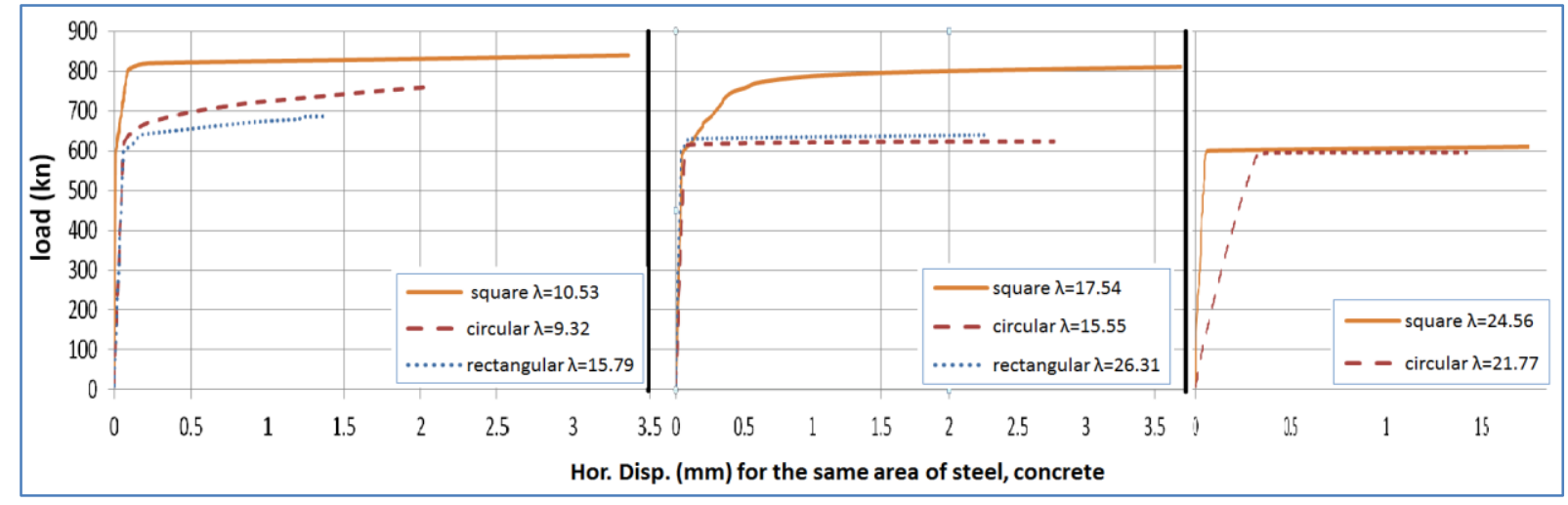

Fig.18. The load-displacement curve for the same $\lambda$

\section{4-4 Ultimate load:}

Table (4) shows the ultimate loads of the CFST columns. From this table it can show that: the ultimate load decreases with increasing the hight of columns for the same shape, because the effect of slenderness ratio. The values of the ultimate load for the square columns are higher than the values of the ultimate load for other shapes of columns, because the higher value of the moment of inertia compared to other shapes. 
Vol. 39, No. 1. January 2020

Table4. Theoretical results with different slenderness ratio

\begin{tabular}{|c|c|c|c|}
\hline Specimens & Length $(\mathbf{m m})$ & Slenderness ratio $(\boldsymbol{\lambda})$ & $\begin{array}{c}\mathbf{P}_{\text {ult. (theo.) }} \\
\mathbf{( N )}\end{array}$ \\
\hline Sq-1 & 1500 & 10.53 & 840000 \\
\hline Sq-2 & 2500 & 17.54 & 810000 \\
\hline Sq-3 & 3500 & 24.56 & 610000 \\
\hline Rec-1 & 1500 & 15.79 & 706440 \\
\hline Rec-2 & 2500 & 26.31 & 721420 \\
\hline Rec-3 & 3500 & 36.80 & Out of limit \\
\hline Cir-1 & 1500 & 9.32 & 780000 \\
\hline Cir-2 & 2500 & 15.55 & 623500 \\
\hline Cir-3 & 3500 & 21.77 & 598000 \\
\hline
\end{tabular}

\section{4-5 Comparison between theoretical and analytical results:}

The ultimate load of the analyzed of CFST column was predicted using equations of Egyptian (ECP) of steel and concrete codes. The reinforced concrete Egyptian code of practice and steel Egyptian code of practice offers two different methods for design and analysis of composite sections under eccentric load.

\section{1- Egyptian concrete code [2]:}

According to the reinforced concrete Egyptian code the following equation has been used in centric load. $\mathrm{P}_{\mathrm{u}}=0.35 \mathrm{f}_{\mathrm{cu}} \mathrm{A}_{\mathrm{c}}+0.67 \mathrm{f}_{\mathrm{yss}} \mathrm{A}_{\mathrm{ss}}+0.67 \mathrm{f}_{\mathrm{ysc}} \mathrm{A}_{\mathrm{sc}}$ Where:

$\mathrm{P}_{\mathrm{u}}=$ ultimate load, $\mathrm{A}_{\mathrm{c}}=$ concrete core area, $A_{s c}=$ longitudinal steel area, $\mathrm{f}_{\mathrm{cu}}=$ concrete compressive strength, $\mathrm{f}_{\mathrm{yss}}=$ steel yield strength for steel plate section,

$\mathrm{A}_{\mathrm{ss}}=$ steel plate area and $\mathrm{f}_{\mathrm{ysc}}=$ steel yield strength for longitudinal steel reinforcement.

\section{2- Egyptian steel code [3]:}

According to the steel Egyptian code the following equations for centric loading had been used.

$$
\text { For, } \quad \begin{array}{ll}
\lambda_{\mathrm{m}} \leq 1.1 & \mathrm{~F}_{\mathrm{cr}}=\left(1-0.348 \lambda_{\mathrm{m}}{ }^{2}\right) \mathrm{F}_{\mathrm{ym}} \\
\lambda_{\mathrm{m}} \geq 1.1 & \mathrm{~F}_{\mathrm{cr}}=0.648 \mathrm{~F}_{\mathrm{ym}} / \lambda_{\mathrm{m}}{ }^{2}
\end{array}
$$

Where:

$$
\begin{aligned}
& \mathrm{F}_{\mathrm{ym}}=\mathrm{F}_{\mathrm{y}}+\mathrm{c}_{1} \mathrm{~F}_{\mathrm{yr}}\left(\mathrm{A}_{\mathrm{r}} / \mathrm{A}_{\mathrm{s}}\right)+\mathrm{c}_{2} \mathrm{~F}_{\mathrm{cu}} \\
& \left(\mathrm{A}_{\mathrm{c}} / \mathrm{A}_{\mathrm{s}}\right) \\
& \mathrm{E}_{\mathrm{m}}=\mathrm{E}_{\mathrm{s}}+\mathrm{c}_{3} \mathrm{E}_{\mathrm{c}}\left(\mathrm{A}_{\mathrm{c}} / \mathrm{A}_{\mathrm{s}}\right) \\
& \lambda_{\mathrm{m}}=\mathrm{L}_{\mathrm{b}}\left(\mathrm{F}_{\mathrm{ym}} / \mathrm{E}_{\mathrm{m}}\right)^{0.5} / \pi \mathrm{r}_{\mathrm{m}}
\end{aligned}
$$

where:

$\mathbf{L}_{\mathbf{b}}=$ buckling length, bigger of inplane and out of plane buckling length,

$\mathbf{r}_{\mathbf{m}}=$ radius of gyration of the steel shape (I/A) $)^{0.5}$

$\mathbf{F}_{\mathbf{y m}}=$ modified yield stress, $\mathbf{F}_{\mathbf{y}}=$ yield stress of steel,

$\phi_{\mathrm{c}}=$ strength reduction factor for compression member, 0.8 ,

$\mathbf{F}_{\mathbf{y r}}=$ yield stress of longitudinal steel reinforcement,

$\mathbf{E}_{\mathbf{m}}=$ modified Young's modulus, $\mathbf{E}_{\mathbf{s}}=$ Young's modulus of steel, $\mathbf{E}_{\mathbf{c}}=$ Young's modulus of concrete, $\mathbf{A}_{\mathbf{r}}=$ area of longitudinal steel reinforcement,

$\mathbf{A}_{\mathbf{s}}=$ area of steel section, pipe or tubing, $\mathbf{A}_{\mathbf{c}}=$ area of concrete,

$\mathbf{c}_{1}, \mathbf{c}_{2}, \mathbf{c}_{3}=$ numerical coefficient taken as follow: $\mathrm{c}_{1}=1, \mathrm{c}_{2}=0.68$ and $\mathrm{c}_{3}=0.4$

$\mathbf{P}_{\mathbf{u}}=$ required compressive strength, 
Table5. Comparison of the theoretical results with equations of Egyptian (CEP) of steel and concrete codes

\begin{tabular}{|c|c|c|c|c|c|c|}
\hline Specimens & $\begin{array}{c}\text { Length } \\
(\mathrm{mm})\end{array}$ & $\begin{array}{c}\text { slenderness } \\
\text { ratio }(\lambda)\end{array}$ & $\begin{array}{c}\mathrm{P}_{\mathrm{u} \text { concrete code }} \\
(\mathrm{N})\end{array}$ & $\begin{array}{c}\mathrm{P}_{\mathrm{u} \text { steel code }} \\
(\mathrm{N})\end{array}$ & $\begin{array}{c}\underline{\mathrm{P}}_{\mathrm{u} \text { concrete code }} \\
\mathrm{P}_{\mathrm{u}} \text { (theo) }\end{array}$ & $\begin{array}{c}\mathbf{P}_{\mathbf{u} \text { steel code }} \\
\mathbf{P}_{\mathbf{u} \text { (theo })}\end{array}$ \\
\hline Sq-1 & 1500 & 10 & 565911 & 722002.43 & 0.67 & 0.86 \\
\hline Sq-2 & 2500 & 16.67 & 565911 & 678202.31 & 0.70 & 0.84 \\
\hline Sq-3 & 3500 & 23.33 & 565911 & 612502.12 & 0.93 & 1.00 \\
\hline Rec-1 & 1500 & 15 & 565911 & 732929.68 & 0.80 & 1.04 \\
\hline Rec-2 & 2500 & 25 & 565911 & 708555.78 & 0.78 & 0.98 \\
\hline Cir-1 & 1500 & 8.86 & 565911 & 718807.51 & 0.73 & 0.92 \\
\hline Cir-2 & 2500 & 14.77 & 565911 & 669327.52 & 0.91 & 1.07 \\
\hline Cir-3 & 3500 & 20.67 & 565911 & 595107.54 & 0.95 & 1.00 \\
\hline
\end{tabular}

The predicted ultimate load capacity $\mathrm{P}_{\mathrm{u}}$ from equations of Egyptian (ECP) of steel and concrete codes versus the ultimate theoretical load capacity $\mathrm{P}_{\mathrm{u}}$ (theo.) for typical analyzed CFST columns are shown in table (5).

For comparison of the analytical results with those estimated using (ECP) of steel and concrete codes, it can be seen the following: the ECP steel code considered the reasonable predicted values of ultimate load capacity of CFST columns due to this equation contains the important parameter of the slenderness ratio of steel section. However, the ECP concrete code gives underestimating the value of ultimate load capacity of CFST columns.

\section{5- CONCLUSION:}

1. The ANSYS (18.1) program is capable to provide a good prediction of the overall behavior of CFST columns.

2. The ultimate load capacity of CFST columns decreased when the slenderness ratio $(\lambda)$ increased for the same shape of the column due to increasing buckling length.
3. For the same slenderness ratio $(\lambda)$, square CFST columns give high ultimate load capacity and stiffness compared to other columns shape because its moment of inertia is greater than the other.

4. At the same load, the value of the displacement increases as the $\lambda$ ratio increased in the same area of concrete and area of steel section.

5. The value of the displacement for CFST columns depending on the slenderness ratio.

6. From the theoretical investigation, it is concluded that the current ECP of concrete code give underestimating the value of ultimate load capacity while, ECP of steel considered the reasonable predicted values for an ultimate load capacity of CFST columns.

\section{REFERENCE:}

1. Chen, W.F. "Plasticity in Reinforced Concrete", Mc Graw - Hill Book Company, 1982.

2. Egyptian code of practice for design of concrete construction, code number (203) 2007. 
3. Egyptian code of practice for steel construction (load and resistance factor design), code number (205) ministerial decree No 359-2007.

4. Han H.L., Tao Z., Huang H. and Zhao X.L. (2004) "Concrete-filled double skin (SHS outer and CHS inner) steel tubular beam-column", Thin walled Structure, Vol.42, No.9, 1329-1355.

5. Han L.H., Li Y.J and Tao Z. (2009) "Influence of Long-Term Loading on the performance of Concrete-Filled Double Skin Steel Tubular column: Experimental", proceeding of the $6^{\text {th }}$ International Conference on Advances in Steel Structures (ICASS'09), Hong Kong.

6. Hasan A. Ajel, Abdulnasser M. Abbas (2015) "Experimental and Analytical Investigations of Composite Stub Columns", International Journal of Innovative Research in Science, Engineering and Technology, Vol. 4, Issue 2.

7. Jingfeng Wang, Beibei Li, Jinchao Li (2017) "Experimental and analytical investigation of semi-rigid CFST frames with external SCWPs" Journal of Constructional Steel Research (128), 289-304

8. Kamal. G. METWALLY, " Shear Transfer of Concrete - Concrete Composite Slabs with Different Shear Span-to-Effective Depth Ratio", Journal of Engineering Science, Cairo university, Vol. 61, No. 5, February 2014.

9. Oliveira, WLA. et al. (2009). "Influence of concrete strength and length/diameter on the axial capacity of CFT columns". Journal of Constructional Steel Research 65(12): 2103-2121.

10. Sasani, M. and Kropelnicki, J. (2008), "Progressive Collapse Analysis of an RC Structure", the Structural Design of Tall and Special Buildings, Vol. 17, pp. 757-771.
11. Tao Z. and Han L.H (2006)" Behavior of concrete filled double skin rectangular steel tubular beamcolumns", Journal of constructional Steel Research, Vol. 62, No. 7, 631-646.

12. Tao Z. and Yu Q. (2006) "New types of composite columns experiments, theory and methodology" Beijing: Science press, Chinese. 


\section{دراسة نظرية لسلوك الأعمدة المركبة من الصلب المفرغ المملوء بالخرسانة}

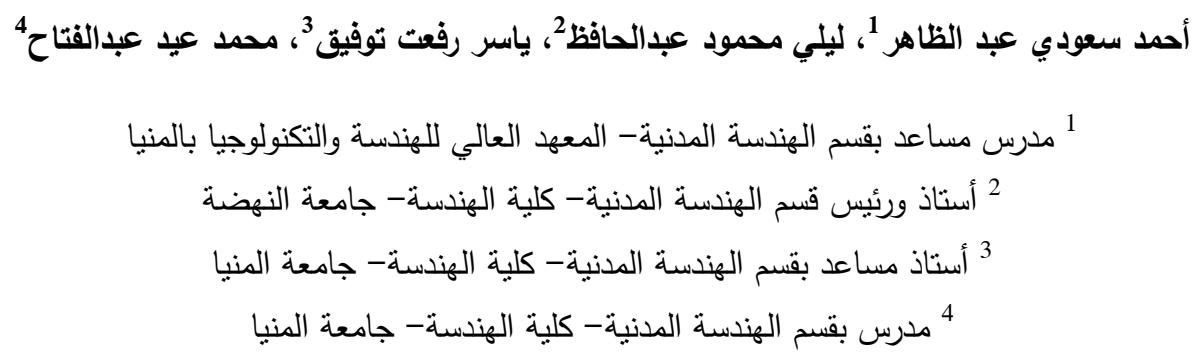

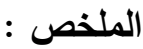

قد انتشر استخدام الأعمدة المركبة من الصلب المفرغ المملوء بالخرسانة في العديد من التطبيقات الهندية مثل المباني العالية والكباري. كما أن استخدام الأعمدة المركبة ليس منوقفاً علي تقليل ابعاد القطاعات الخرسانية فقط بل لكافئتها العالية وممطوليتها. ومن اهم مديزات هذه الأعمده أنها تمنع حدوث الإنبعاج لقطاع الصلب الخارجي وبالإضافة إلي عدم استخدام فورم خشبيه لصب العمود. لذا فإن هذه الورقة البحثية تهدف إلي دراسة نظرية لسلوك الأعمدة المركبة من الصلب المفرغ المملوء بالخرسانه المعرضه لحمل محوري باستخدام برنامج ANSYS. وهذه الدراسة تتقسم إلي حزئين: الجزء الأول : تم إجراء مقارنة للنتائج المعلية لدراسة سابقة بالنتائج النظرية باستخدام برنامج ANSYS وتبين أنه يوجد نطابق ملحوظ بينهما. وفي الجزء الثاني: دراسة بعض المتغيرات المؤثرة علي سلوك الأعمدة المركبة المقيدة ذات مساحة قطاع خرساني وصلب ثابته تحت تأثثر حمل محوري. وكانت المتغيرات الرئيسة هي شكل مقطع الأعمدة ونم استخدام ثلاث اثكال وهي (مربع ومستطيل وائري) ونسبة النحافه لكل شكل. وتبين من هذه الدراسة النظرية أن عند زيادة نسبة النحافة أدت إلي قلة الحمل الأقصي وجساءة وممطولية العمود. وعند مقارنة هذه النتائج بمعادلات الكود المصري للخرسانة والصلب تبين أنها اقل من قيم نتائج الكود الخرساني بينما تكون مناسبة لقيم نتائج كود الصلب وذلك لأن الكود الخرساني يتجاهل الخرسانة المحصوره بين القطاع 